\title{
Author Correction: Highly pathogenic H5N6 avian influenza virus subtype clade 2.3.4.4 indigenous in South Korea
}

\author{
Juyoun Shin, Shinseok Kang, Hyeonseop Byeon, Sung-Min Cho, Seon-Yeong Kim, \\ Yeun-Jun Chung \& Seung-Hyun Jung
}

Correction to: Scientific Reports, https://doi.org/10.1038/s41598-020-64125-x, published online 29 April 2020

This Article contains errors. The authors reports that samples were collected from allantoic fluid; they were collected from fecal samples. The authors also reported incorrect biosafety level for the facilities where the experiments were performed.

In Materials and Methods, 'Sample sites and sample collection',

"After HA activity testing, viral RNA was extracted from the HA-positive allantoic fluid using QIAamp Viral RNA Mini Kit (QIAGEN, Hilden, Germany). Approval for this study was obtained from the Institutional Animal Care and Use Committee at Chungcheongbuk-do Veterinary Service Laboratory (\#2019-2) and all experimental procedures from virus isolation to sequencing library preparation were conducted in approved biosafety level 3 (BSL3) facilities (KCDC-12-3-04) at Chungbuk Veterinary Service Laboratory."

should read:

"After HA activity testing, viral RNA was extracted from the HA-positive fecal samples using QIAamp Viral RNA Mini Kit (QIAGEN, Hilden, Germany). Approval for this study was obtained from the Institutional Animal Care and Use Committee at Chungcheongbuk-do Veterinary Service Laboratory (\#2019-2) and all experimental procedures from virus isolation to sequencing library preparation were conducted in approved biosafety level 2 (BSL2) facilities (QIA-GA2-16-015) at Chungbuk Veterinary Service Laboratory joongbu."

(c) (i) Open Access This article is licensed under a Creative Commons Attribution 4.0 International License, which permits use, sharing, adaptation, distribution and reproduction in any medium or format, as long as you give appropriate credit to the original author(s) and the source, provide a link to the Creative Commons license, and indicate if changes were made. The images or other third party material in this article are included in the article's Creative Commons license, unless indicated otherwise in a credit line to the material. If material is not included in the article's Creative Commons license and your intended use is not permitted by statutory regulation or exceeds the permitted use, you will need to obtain permission directly from the copyright holder. To view a copy of this license, visit http://creativecommons.org/licenses/by/4.0/.

(C) The Author(s) 2020 